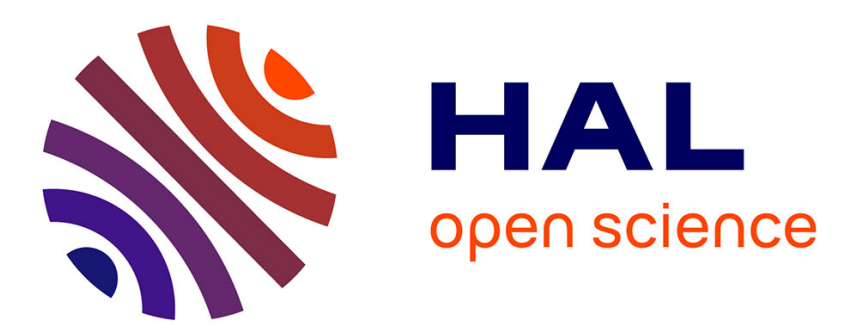

\title{
Surface performances of Ti-6Al-4V substrates coated PVD multilayered films in biological environments
}

\author{
R. Bahi, Corinne Nouveau, N.E. Beliardouh, C.E. Ramoul, S. Meddah, O.
} Ghelloudj

\section{- To cite this version:}

R. Bahi, Corinne Nouveau, N.E. Beliardouh, C.E. Ramoul, S. Meddah, et al.. Surface performances of Ti-6Al-4V substrates coated PVD multilayered films in biological environments. Surface and Coatings Technology, 2020, 385, pp.125412. 10.1016/j.surfcoat.2020.125412 . hal-03065170

\author{
HAL Id: hal-03065170 \\ https://hal.science/hal-03065170
}

Submitted on 14 Dec 2020

HAL is a multi-disciplinary open access archive for the deposit and dissemination of scientific research documents, whether they are published or not. The documents may come from teaching and research institutions in France or abroad, or from public or private research centers.
L'archive ouverte pluridisciplinaire HAL, est destinée au dépôt et à la diffusion de documents scientifiques de niveau recherche, publiés ou non, émanant des établissements d'enseignement et de recherche français ou étrangers, des laboratoires publics ou privés. 


\title{
Surface performances of Ti-6Al-4V substrates coated PVD multilayered films in biological environments
}

\author{
R. Bahi ${ }^{\mathrm{a}}$, C. Nouveau ${ }^{\mathrm{b}}$, N.E. Beliardouh ${ }^{\mathrm{a}, *}$, C.E. Ramoul ${ }^{\mathrm{a}, \mathrm{c}}$, S. Meddah ${ }^{\mathrm{c}}$, O. Ghelloudj

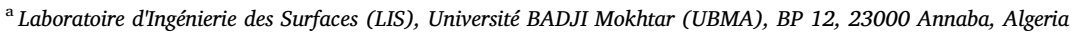 \\ ${ }^{\mathrm{b}}$ Arts et Métiers, Institute of Technology, LaBoMaP, HESAM Université, Rue Porte de Paris, F-71250 Cluny, France \\ ${ }^{\mathrm{c}}$ Research Center in Industrial Technologies CRTI, P.O. Box 64, Cheraga, 16014 Algiers, Algeria
}

\section{A R T I C L E I N F O}

\section{Keywords:}

PVD-coatings

Oxides

Nitrides

Biomaterials

Tribology

Corrosion

\begin{abstract}
A B S T R A C T
Multilayered and nanostructured coatings of Ti based alloys (oxides and nitrides) are elaborated and tested for increasing protective properties such as corrosion and wear resistances. A pin-on-disc tribometer was used to evaluate the wear resistance in Hank's solution against bovine bone. Corrosion behavior in Hank's solution was determined by potentiodynamic and electrochemical impedance spectroscopy techniques. Besides, the specimen surfaces were characterized by Atomic Force Microscopy (AFM), Scanning Electron Microscopy (SEM) and Energy Dispersive Spectroscopy (EDS) microanalyses. The results showed that optimal tribological properties were obtained in the case of coatings having TiN as top layer. The main wear mechanism was abrasive third body wear. In vitro corrosion tests at $37{ }^{\circ} \mathrm{C}$ showed that the better corrosion resistance was obtained when TiN was the top layer. However all of them exhibited good tribological properties, good corrosion resistance and then may be promising options for biomedical applications.
\end{abstract}

\section{Introduction}

The challenge in biomedical implants is to improve mechanical properties and corrosion resistance as well as biocompatibility at low cost. Ti-6Al-4V alloy is one of the most common materials used as orthopedic implants into the human body. It has good mechanical properties and favorable biocompatibility in addition to an excellent resistance against wear and corrosion in aggressive environments [1,2]. However, it was indicated that Aluminum and Vanadium had a negative biological responses because of their toxicity effects caused by the dissolution of $\mathrm{Al}$ and $\mathrm{V}$ ions in the human body $[3,4]$. On another hand, poor tribological behavior of Ti-6Al-4V alloy leads to a fine wear debris causing allergy and inflammation. Another disadvantage is that caused by the high difference between elastic moduli of the antagonists in contact i.e. implant and bone; E (Ti-6Al-4V) is around $114 \mathrm{GPa}$ [5], while $\mathrm{E}$ (bone) is nearly $30 \mathrm{GPa}$ [6]. Consequently, inconveniences mentioned above lead to a decrease in the service life of the prosthesis $[7,8]$.

To enhance mechanical properties, biocompatibility, osseointegration, wear and corrosion resistance, protecting the Ti-6Al-4V substrates by PVD layers was proven to be a promising solution. TiN and $\mathrm{TiO}_{2}$ are among coatings used as protective because of their non-toxicity, good stability, ease of mass production and high controllability $[9,10]$. Since the last two decades, many researchers have shown that multilayer coatings, especially metal/ceramic sequences, improve the mechanical properties of the coating and their resistance to higher corrosion compared to monolayer coatings [11-15]. Several interlayers should be deposited on the substrate and below external coating surface. It's found that ductile titanium in the intermediate layers in coatings can reduce internal stresses and improve toughness of hard coatings [16]. The surface of titanium alloy is naturally covered by a passive layer of titanium dioxide $\left(\mathrm{TiO}_{2}\right)$, when in contact with biological environments. Thus, passive layer create an interface between the surrounding tissue and the implant promoting osseointegration [17-19].

In the present work, new design of multilayer coatings was elaborated by DC magnetron sputtering and evaluated for their suitability as protective coatings for biomedical implants. The tribological behavior (against bone) and corrosion behavior in Hank's solution of the (Ti/ TiN) ${ }_{9}$ and $(\mathrm{Ti} / \mathrm{TiN})_{9} / \mathrm{TiO}_{2}$ systems have been analyzed and compared.

Multilayer coatings, used in this study, alternating successively hard phase/ductile phase are a biomimetic design inspired from nature (nacre-inspired materials and coatings [20,21]). Hank's solution is the most widely used simulated human body fluid, in corrosion tests as an aggressive medium and in wear tests as a bio-lubricant. Wang et al. [22] reported that bio-lubricants should be considered to be an important factor on the tribological behavior of bone and titanium alloys. The

\footnotetext{
* Corresponding author.

E-mail addresses: beliardouh_23@yahoo.fr, nebeliardouh23@gmail.com (N.E. Beliardouh).
} 


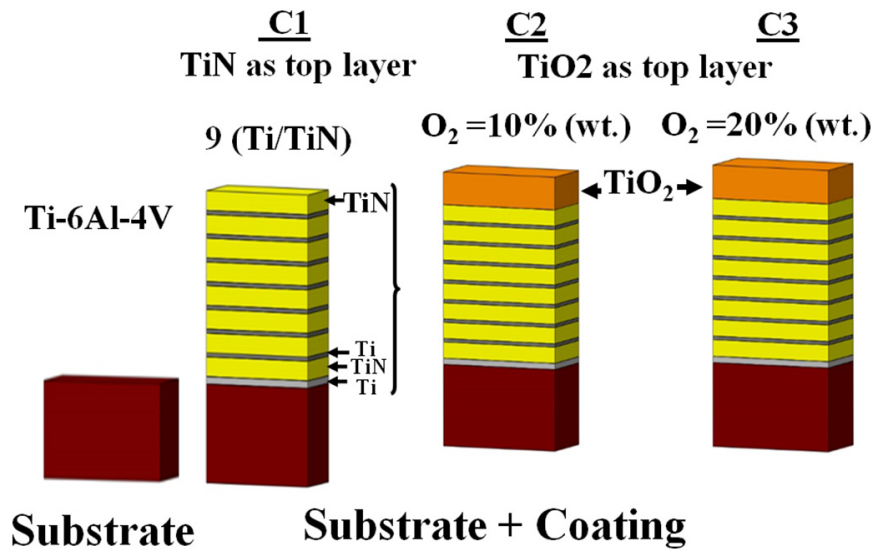

Fig. 1. Scheme of the studied multilayered coatings on Ti-6Al-4V substrates.

extreme conditions of tests, used in this study, are far from being the case in vivo, however accidents may result and they could be an effective tool when choosing the appropriate material for the specific implant.

\section{Materials and methods}

\subsection{Coatings deposition}

Coatings were elaborated by reactive DC magnetron sputtering (KENOSISTEC KV40 system), using a high-purity Ti target (99.95\%). Ti$6 \mathrm{Al}-4 \mathrm{~V}$ substrates were intended for tribological and corrosion tests $\left(\varnothing=20 \mathrm{~mm} \times 5 \mathrm{~mm}, \mathrm{R}_{\mathrm{a}}=165 \pm 5 \mathrm{~nm}\right)$ and Silicon (100) wafer substrates $\left(10 \mathrm{~mm} \times 10 \mathrm{~mm} \times 0.38 \mathrm{~mm}, R_{a}=1 \mathrm{~nm}\right)$ were used for nondestructive analysis. Coating specimens deposited on $\mathrm{Si}$ substrates were cut longitudinally with a diamond tip before SEM observation of the cross section. The Ti-6Al-4V and Si (100) substrates were ex-situ ultrasonically cleaned for $10 \mathrm{~min}$ in acetone and deionized water successively. Fig. 1 shows a scheme of the multilayer coatings elaborated in the present work. The design consists of a pure Ti metal under layer $(\sim 100 \mathrm{~nm})$ for all the samples. Afterwards, alternating (Ti/TiN) layers were performed by controlling the reactive nitrogen flow (purity: 99.999\%). Specimens "type C1" are composed of substrate + nine repeating Ti/TiN layers ( $\sim 180 \mathrm{~nm}$ thick); which means a total of eighteen (18) layers. Specimens "type C2" and "type C3" were elaborated firstly as well as $\mathrm{C} 1$. Then, the nitrogen flow was stopped and oxygen (purity: 99.995\%) was introduced into the chamber. The process was conducted with a continuous gas flow (mixing $\mathrm{Ar}+\mathrm{O}_{2}$ ) ensured by an MKS massflow controller during $720 \mathrm{~s}$. The pressure was kept constant at the level of $0.5 \mathrm{~Pa}$. The focus is to form a $\mathrm{TiO}_{2}$ film as a top layer $(\sim 200 \mathrm{~nm})$. Two $\mathrm{O}_{2}$ partial pressures are employed i.e. $\mathrm{O}_{2} / \mathrm{Ar}$ ratio $=0.12$ and $\mathrm{O}_{2} /$ Ar ratio $=0.26$ during the elaboration of $\mathrm{C} 2$ and $\mathrm{C} 3$ specimens respectively. The deposition parameters are summarized in Table 1.

Table 1

Deposition parameters.

\begin{tabular}{llll}
\hline \multirow{2}{*}{ Gas mixture } & \multicolumn{3}{l}{ Coatings } \\
\cline { 2 - 4 } & $\mathrm{Ti}$ & $\mathrm{TiN}$ & $\mathrm{TiO}_{2}$ \\
\hline Ar flow (sccm) & 95 & 68.8 & 90 \\
$\mathrm{~N}_{2}$ flow (sccm) & - & 33.3 & - \\
$\mathrm{O}_{2}$ flow (sccm) & - & - & $(\mathrm{C} 2=11),(\mathrm{C} 2=24)$ \\
Target-substrate distance & $120 \mathrm{~mm}$ & & \\
Substrate bias voltage & $-350 \mathrm{~V}$ & & \\
Residual pressure $(\mathrm{Pa})$ & $2.10^{-5}$ & & \\
Working pressure $(\mathrm{Pa})$ & 0.5 & & \\
\hline
\end{tabular}

Table 2

Thickness, adhesion and chemical composition of the layers.

\begin{tabular}{|c|c|c|c|c|c|c|}
\hline \multirow[t]{2}{*}{ Samples } & \multirow[t]{2}{*}{ Thickness $(\mu \mathrm{m})$} & \multicolumn{2}{|l|}{ Adhesion test } & \multicolumn{3}{|c|}{ Contents (at.\%) } \\
\hline & & $\mathrm{L}_{C 1}(\mathrm{~N})$ & $\mathrm{L}_{C 2}(\mathrm{~N})$ & $\mathrm{N}$ & $\mathrm{O}$ & $\mathrm{Ti}$ \\
\hline $\mathrm{C} 1$ & 1.6 & $9.02 \pm 1.5$ & $30.16 \pm 0.6$ & 4.2 & 6.3 & 89.5 \\
\hline $\mathrm{C} 2$ & 2.6 & $9.27 \pm 0.7$ & $32.24 \pm 0.5$ & 0 & 13.5 & 86.5 \\
\hline $\mathrm{C} 3$ & 2.0 & $9.5 \pm 0.5$ & $32.5 \pm 0.5$ & 0 & 27.9 & 72.2 \\
\hline
\end{tabular}

\subsection{Characterizations}

\subsubsection{Coating adhesion}

Coating adhesion was evaluated by scratch test. The lower critical load $\mathrm{L}_{C 1}$ (cohesive failure) and the critical load $\mathrm{L}_{C 2}$ (adhesive failure) were measured with a CSM Instruments scratch tester equipped with a diamond stylus (Rockwell $\mathrm{C}, 200 \mu \mathrm{m}$ radius tip) under progressive loading conditions of 1-50 N, with a $5 \mathrm{~mm}$ scratch length. All specimens are tested in the same conditions (Table 2).

\subsubsection{Corrosion}

Electrochemical investigations were carried out with Autolab potentiostat/galvanostat in $100 \mathrm{ml}$ of the Hanks' solution at $37{ }^{\circ} \mathrm{C}$ $\left(\mathrm{pH}=7\right.$, and composition in (g/l): $8.0 \mathrm{NaCl}, 0.4 \mathrm{KCl}, 0.2 \mathrm{MgSO}_{4} \cdot 7 \mathrm{H}_{2} \mathrm{O}$, $0.16 \mathrm{CaCl}_{2} \mathrm{H}_{2} \mathrm{O}, 0.04 \mathrm{Na}_{2} \mathrm{HPO}_{4}, 0.06 \mathrm{KH}_{2} \mathrm{PO}_{4}, 0.35 \mathrm{NaHCO}_{3}$, and 1.0 Glucose). The temperature of the electrolyte was controlled by thermostat with water recirculation at $37 \pm 1{ }^{\circ} \mathrm{C}$. Global measurements were performed using a classical three-electrode cell; $\mathrm{Pt}$ and $\mathrm{Ag} / \mathrm{AgCl}$ (3M KCl solution) are employed as counter and reference electrodes, respectively. The electrochemical impedance spectroscopy (EIS), was performed at open circuit potential (OCP) after a time period of $1 \mathrm{~h}$. The frequency range was from $10^{5} \mathrm{kHz}$ to $10^{-2} \mathrm{~Hz}$ at a rate of 5 points/ decade in $\mathrm{E}_{\text {ocp }} \mathrm{vs} \mathrm{Ag} / \mathrm{AgCl}$ and the amplitude was set at $10 \mathrm{mV}$. The potentiodynamic polarization test was raised from $-1 \mathrm{~V}$ to $+1 \mathrm{~V}$, at a scan rate of $1 \mathrm{mV} / \mathrm{s}$. Before the test, specimens were immersed in the electrolyte for $2 \mathrm{~h}$ to attain stable open circuit potential (OCP). The polarization resistance $\left(R_{p}\right)$ was estimated from Tafel curves using Stern-Geary equation as follows:

$$
R_{p}=\frac{\beta_{a} \times \beta_{c}}{2.3039(\beta a+\beta c)} \times \frac{1}{I_{c o r r}}
$$

where $\beta_{a}, \beta_{c}$ are the slopes of anodic and cathodic Tafel plots.

\subsubsection{Tribology}

Bovine cortical bone was designed to be the upper friction counterpart against rotating Ti-6Al-4V, C1, C2, and C3 disc specimens to further simulate their (bone) in vivo tribological behavior. As this is not possible to have spherical ball from organic matter of animal origin (cartilage, bone, etc.), the pin-on-disc configuration provided by (CCSM Instruments (Switzerland) tribometer is perfectly adapted for this case and is described in details in a previous work [23]. The bone pins were prepared (cylinder $\emptyset=6 \mathrm{~mm} \times 20 \mathrm{~mm}$, Ra $=0.73 \mu \mathrm{m}$ ) from a bovine femur. Wear tests were conducted in accordance to the ASTM G99-95a to determine the coefficient of friction (COF). The geometry of the pinon-disc tests is shown in Fig. 2. During the tests, discs were completely immerged in Hank's solution. The flowing parameters were kept constant: applied load $(N=3 \mathrm{~N})$, sliding speed $(\mathrm{v}=5 \mathrm{~cm} / \mathrm{s})$ and track radius $(r=4 \mathrm{~mm}$ ). The sliding distance of $100 \mathrm{~m}$ was long enough to produce a breakdown of the coating. The specific wear rate was obtained by the classical formula as follows:

$$
\mathrm{W}_{\mathrm{s}}=\frac{\mathrm{V}}{\mathrm{NL}}\left(\mathrm{mm}^{3} / \mathrm{Nm}\right)
$$

where $W_{s}$ is the specific wear rate, $V$ is the wear volume $\left[\mathrm{mm}^{3}\right], N$ is the normal load $[\mathrm{N}]$ and $\mathrm{L}$ is the sliding distance $[\mathrm{m}]$. The $\mathrm{W}_{\mathrm{s}}$ estimation was automatically obtained by short software [23] using 3D 


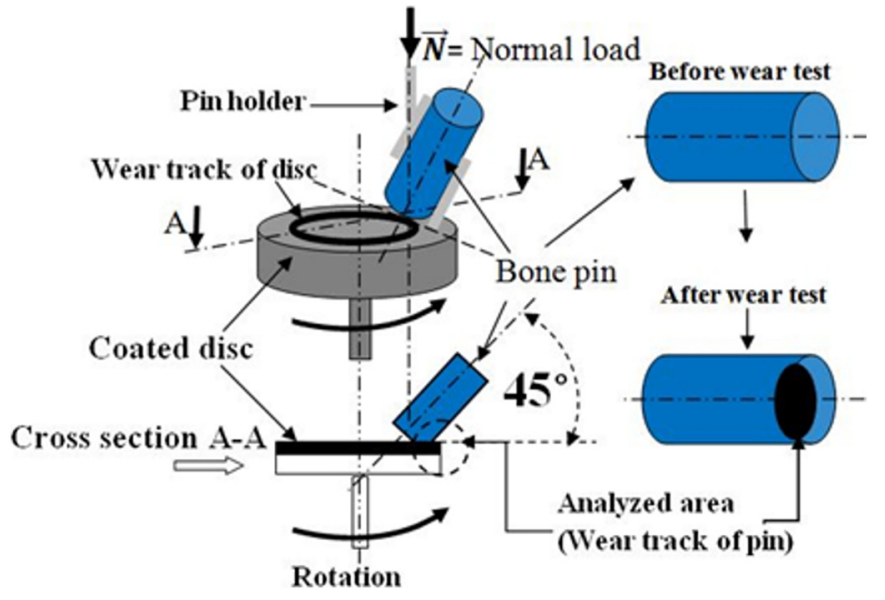

Fig. 2. Schematic of the pin-on-disc test.

profilometry image (Optical profilometer VEECO, Wyko NT-1100). The surface morphologies of discs and pins were examined by SEM/EDS (JEOL JSM-5900-LV microscope).

\subsubsection{Surface roughness and structure}

The roughness of coatings on Ti-6Al-4V substrates was determined using a 3D profilometer while roughness of the coatings on $\mathrm{Si}(100)$ substrates was obtained by using an atomic force microscope (AFM, Explorer, VEECO Topometrix). The scanning area of each image was set at $5 \mu \mathrm{m} \times 5 \mu \mathrm{m}$ with a scanning rate of $1.0 \mathrm{~Hz}$ to obtain a detailed surface image. The structure of the coatings was analyzed by X-ray Diffraction (Bruker diffractometer; radiation source $(\lambda)$ $\mathrm{Co}_{(\mathrm{K} \alpha)}=0.1789 \AA$ ). The diffraction scanning angle ranges from 20 to $80^{\circ}$ at a scanning rate of $1^{\circ} / \mathrm{min}$.

\section{Results and discussion}

\subsection{Microstructural characterization}

Prior to any microstructural analysis, the microstructural phases must be identified. XRD analyses were carried out by using the conventional symmetrical Bragg-Brentano configuration on C1, C2 and C3 samples to determine the structure of the top layer on the specimen. Fig. 3 shows the XRD patterns that highlight the crystallinity of the deposited films on $\mathrm{Si}$ (100) substrates. It shows, for C1 C2 and C3 specimens, typical diffraction peaks of TiN phase ((111) at $2 \Theta=41.313^{\circ}$ and $(200)$ at $\left.2 \Theta=47.16^{\circ}\right)$, Ti (200) at $2 \Theta=44.96^{\circ}$ and

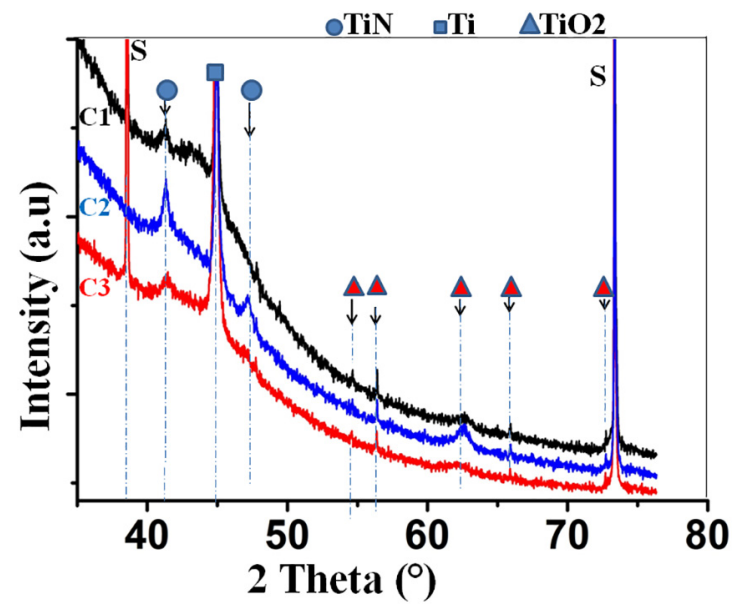

Fig. 3. XRD patterns of C1, C2 and C3 multilayer films. Symbols indicated the $2 \Theta$ standard positions ( $\mathrm{S}=$ substrate).
$\mathrm{TiO}_{2}$ anatase phase $\left((112)\right.$ at $2 \Theta=54.65^{\circ},(211)$ at $2 \Theta=56.45^{\circ},(220)$ at $2 \Theta=62.68^{\circ},(221)$ at $2 \Theta=65.95^{\circ}$, and $(113)$ at $2 \Theta=72.94^{\circ}$ ) according to the standard ICDD cards $\mathrm{N}^{\circ}$ 01-074-1214, 00-044-1294 and 01-071-1169 respectively and compared with available literature $[10,16]$. Peaks at $2 \Theta=38.63^{\circ}$ and $73.413^{\circ}$ are related to the substrate i.e. Si (200) and Si (400) respectively (ICDD card $\left.\mathrm{N}^{\circ} 00-027-1402\right)$. Our findings provide a unique anatase phase for the two oxygen flow. It was suggested that the selective crystal phase of $\mathrm{TiO}_{2}$ thin films (rutile, anatase) is based on the oxygen concentration during reactive magnetron sputtering [24].

Remark: the strongest picks related to Si substrate $\left(2 \theta>80^{\circ}\right)$ were voluntary removed from XRD patterns.

Fig. 4 shows the cross sections and surface morphology of the multilayer films. One can observe that the coatings fully cover the Ti6Al-4V substrates. Fig. 4(a-c) depicts the cross-section SEM images of $\mathrm{C} 1, \mathrm{C} 2$ and $\mathrm{C} 3$, respectively. It is shown the typical columnar structure of PVD coatings i.e. vertically aligned nanocolumns; the largest horizontal section, are between 70 and $120 \mathrm{~nm}$. The sequence (horizontal) of the alternating layers appears clearly; the sharp boundaries are seen at the different interfaces; it is then possible to count directly the alternated layers of TiN and to estimate approximately the size of the nanocrystallites. The SEM images in Fig. 4(d-f) show that TiN (Fig. 4d) presents a different surface morphology in comparison to the $\mathrm{TiO}_{2}$ one (Fig. 4(e-f)). Moreover, "protuberances" and micropores are observed at both $\mathrm{TiN}$ and $\mathrm{TiO}_{2}$ surfaces. A fine microstructure constituted by small grains with narrow size distribution was shown in the case of TiN films. Surfaces of $\mathrm{TiO}_{2}$ films show almost spherical agglomerates of columns. They also present a compact and homogeneous surface morphology but some irregularities such as pores are clearly seen. The composition of the surface layers was analyzed by EDS microanalyses. The total thickness of the coatings and the final chemical compositions are listed in Table 2.

Fig. 5 shows the three dimensional AFM images of TiN (C1) and $\mathrm{TiO}_{2}$ (C2 and C3) coatings surface. It is obvious that all the films have a compact structure with several "keen peaks" i.e. column tops. The roughness of these thin films was characterized according to $R_{a}$ (Roughness average) and $\mathrm{R}_{\mathrm{q}}\left(\mathrm{R}_{\mathrm{q}}=\right.$ Root Mean Square). As presented in Fig. 5, the deposited films have very low surface roughness. There are no significant differences in roughness between films except $\mathrm{C} 1$ that has a slightly superior $\mathrm{R}_{\mathrm{q}}$ in comparison to $\mathrm{C} 2$ and C3. It is also shown in Fig. 5 that the size of the columnar surface related to the $\mathrm{TiO}_{2}$ upper layer (C2 or C3) are higher when compared to TiN upper layer (C1). Besides, C2 and C3 present similar surface topography $\left(R_{a}, R_{q}\right)$. So, in the case of the $\mathrm{TiO}_{2}$ film, the oxygen content seems to have no influence upon "nanofeatures of surface". More details are presented in Table 3. The AFM quantitative results are within the range obtained by similar works [25].

\subsection{Electrochemical analysis}

One of the basic criteria to choose the material to be implanted into human (animal) body is the corrosion resistance in Hank's solution. Body fluids are aggressive and corrosive media for biomaterials. In terms of corrosion, a large number of ions $\left(\mathrm{Na}^{+}, \mathrm{Cl}^{-}, \mathrm{Ca}^{2+}, \mathrm{SO}_{4}{ }^{2-} \ldots\right)$ in addition to organic acids in Hank's solution would reduce the stability of the passive film, resulting in the most negative potential owing to more exposed metal surfaces, and finally damage and deterioration of the implant.

\subsubsection{Potentiodynamic polarization curves}

Fig. 6 presents the polarization curves of uncoated (Ti-6Al-4V substrate) and coated (C1, C2 and C3) Ti-alloy samples in Hank's solution at $37{ }^{\circ} \mathrm{C}$. The multilayer coatings improve the corrosion resistance of substrate. Lower corrosion current density $\left(\mathrm{i}_{\text {corr }}\right)$ and higher corrosion potential $\left(\mathrm{E}_{\mathrm{corr}}\right)$ indicate that the sample has relatively excellent corrosion resistance. From Fig. 6, it was obvious that the C1 surface sample 
a)
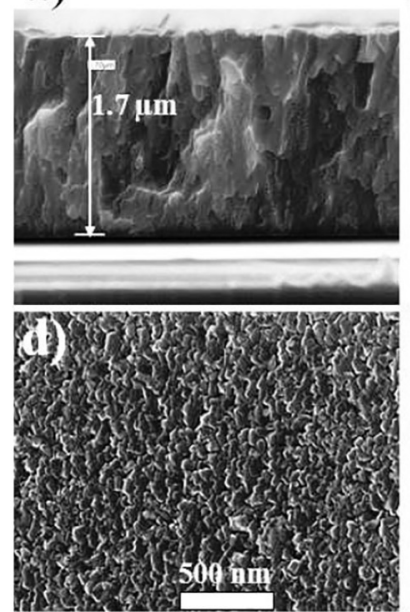

$\underline{\text { C1 }}$ b)
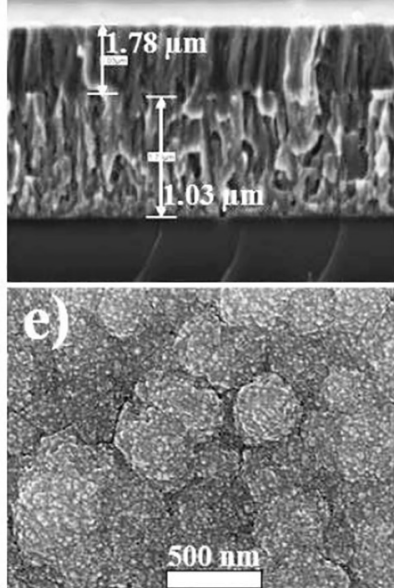

$\underline{\mathrm{C} 2}$ c)
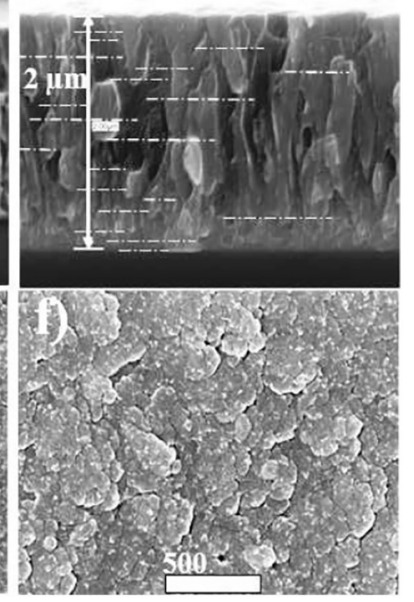

$\underline{\mathrm{C} 3}$

Fig. 4. SEM cross sections of the deposited films: (a) C1, (b) C2 and (c) C3. SEM surface morphologies of (d), C1, (e) C2 and (f) C3.

exhibited the highest corrosion resistance which can be observed by a shift in the noble direction of the whole polarization curves towards the region of lower current density and higher potential. However, when passive films are on their steady state $(+0.2 \mathrm{~V} /(\mathrm{Ag} / \mathrm{AgCl}))$, the passive current density tendency of C2 sample increases slightly relatively to Ti$6 \mathrm{Al}-4 \mathrm{~V}$ sample. The electrochemical corrosion parameters, including the corrosion current density ( $\mathrm{i}_{\text {corr }}$ ), corrosion potential $\left(\mathrm{E}_{\text {corr }}\right)$ and $\mathrm{R}_{\mathrm{p}}$ are displayed in Table 4. Quantitative parameters from Table 4 indicate that $i_{\text {corr }}$ of $\mathrm{C} 1$ is almost $0.05 \mu \mathrm{A} / \mathrm{cm}^{2}$ and $E_{\text {corr }}$ is practically equal to zero $\mathrm{V}(\mathrm{Ag} / \mathrm{AgCl})$. The current density of $\mathrm{C} 1$ specimen was lower by two (02) orders in magnitude at least, when compared to the others. The uncoated Ti-6Al-4V substrate exhibited the highest corrosion potential $\left(\mathrm{E}_{\text {corr }}=-0.38 \mathrm{~V} /(\mathrm{Ag} / \mathrm{AgCl})\right)$ and a slightly lower $\mathrm{i}_{\text {corr }}$ than $\mathrm{C} 2$. Based on quantitative $R_{p}$ values the obtained results show that: $C 1>C 3>$ Ti-6Al-4 V > C2 (Table 4).

From the potentiodynamic polarization curves, it can be concluded that $\mathrm{C} 1$ coating has the best chemical stability in the corrosive environment, suggesting that nitride coating surface improved enough the corrosion resistance of Ti-6Al-4V substrate. This can be explained by the compact nitride layer acting as a barrier to corrosion [26]. The protective nature of the multilayer coating $\mathrm{Ti} / \mathrm{TiN}$ surface (higher number of bilayers) in Hank's solution could be attributed to their lower porosity, among others surface characteristics as suggested by Shukla et al. [10]. This is confirmed by the obtained results for $\mathrm{C} 1$ when compared to $\mathrm{TiO}_{2}$ and Ti-6Al-4V surfaces. The finding corrosion parameters are in the same order of magnitude and in good agreement with literature [10], [27-30].
Table 3

AFM Roughness average values.

\begin{tabular}{llllll}
\hline Sample & Si substrate & & & \multicolumn{2}{l}{ T-6Al-4V substrate } \\
\cline { 2 - 3 } \cline { 5 - 6 } & $\begin{array}{l}\mathrm{R}_{\mathrm{a}} \\
(\mathrm{nm} \pm 2)\end{array}$ & $\begin{array}{l}\mathrm{R}_{\mathrm{q}} \\
(\mathrm{nm} \pm 2)\end{array}$ & $\begin{array}{l}\mathrm{R}_{\mathrm{a}} \\
(\mathrm{nm} \pm 3)\end{array}$ & $\begin{array}{l}\mathrm{R}_{\mathrm{q}} \\
(\mathrm{nm} \pm 3)\end{array}$ \\
\hline C1 & 5 & 8 & 65 & 95 \\
C2 & 7 & 6 & 70 & 97 \\
C3 & 5 & 6 & 58 & 75 \\
\hline
\end{tabular}

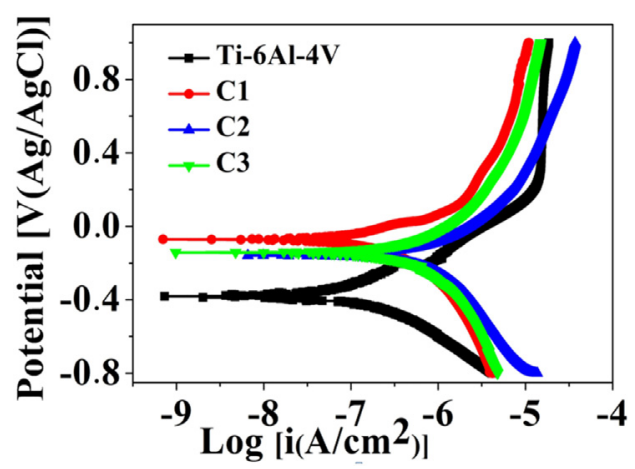

Fig. 6. Polarization resistance of the tested specimens in Hank's solution at $37^{\circ} \mathrm{C}$.
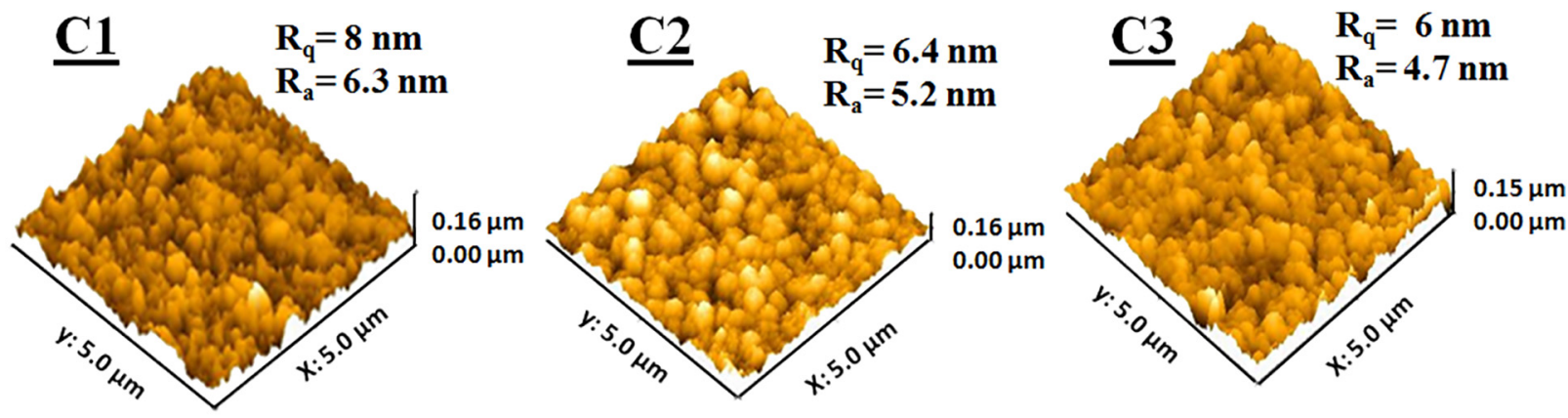

Fig. 5. AFM images of the C1, C2 and C3 multilayer films deposited on Si substrates. 
Table 4

Potentiodynamic polarization parameters of different coatings in Hank's solution at $37^{\circ} \mathrm{C}$. Data are the average values of three tests.

\begin{tabular}{llllll}
\hline Sample & $\beta_{\mathrm{a}}(\mathrm{V} / \mathrm{dec})$ & $\beta_{\mathrm{c}}(\mathrm{V} / \mathrm{dec})$ & $\mathrm{E}_{\text {corr }}(\mathrm{V})$ & $\begin{array}{l}\mathrm{i}_{\text {corr }} \\
\left(\mathrm{A} / \mathrm{cm}^{2}\right) \cdot 10^{-6}\end{array}$ & $\mathrm{R}_{\mathrm{p}}(\Omega)$ \\
\hline Ti-6Al-4V & 0.309 & 0.185 & -0.345 & 0.117 & 490841.17 \\
C1 & 0.169 & 0.252 & -0.071 & 0.049 & 896077.23 \\
C2 & 0.222 & 0.320 & -0.156 & 0.152 & 364074.30 \\
C3 & 0.243 & 0.317 & -0.142 & 0.105 & 568623.21 \\
\hline
\end{tabular}

\subsubsection{Electrochemical impedance spectroscopy}

Fig. 7 displays the electrochemical impedance spectroscopy results obtained for Ti-6Al-4V substrate and the coatings tested in Hank's solution at $37^{\circ} \mathrm{C}$. The Nyquist plot for each tested specimen appears to be arc of a semicircle (Fig. 7a). It can be easily confirmed that: (i) all the coatings (C1, C2 and C3) show larger radius of curvature than Ti-6Al$4 \mathrm{~V}$ substrate; (ii) two loops are clearly shown in the low and in the medium frequency range of the Nyquist plots (insert image in Fig. 7a). The larger diameter of the curvature sample suggested that it offers higher resistance to charge transfer process. EIS data in Bode plots (Fig. 7(b-c)) confirm the highly electrochemical performances of C1 and the lowest performance of Ti-6Al-4V substrate. Two time constants are observed for all of the specimens. Then two capacitive behaviors occurred for the entire tested specimens. Such behaviors indicate improved passive film properties in such conditions, already observed in potentiodynamic technique (Fig. 6).

Fig. 7d indicates the selected electrical equivalent circuit model for all the specimens. This model was proposed in the literature for Ti-6Al$4 \mathrm{~V}$ [31], Ti-6Al-4V coated Ti/TiN multilayer coatings [10] and Ti-6Al-4V coated $\mathrm{TiO}_{2}$ [27].

\subsubsection{Ti-6Al-4V substrate specimen}

Reviewed literatures showed some controversy about the selected equivalent circuit (EC) modeling the electrochemical behavior of Ti-6Al-4V alloy in Hank's solution at $37{ }^{\circ} \mathrm{C}$. However, all of them $[27,28-35]$, agree that there was evidence of the formation of a twolayer oxide film (essentially $\mathrm{TiO}_{2}$ [35]) composed of dense inner layer and porous outer layer. In this case, the EC model consists with Hank's solution resistance $R_{s}$. R1, CPE1 are resistance and capacitance of porous layer (outer) with the electrolyte inside pore and R2, CPE2; resistance and capacitance of the barrier layer (inner). Detailed fitting data are listed in Table 5 . The resistance of the outer layer $(\mathrm{R} 1 \sim 6 \mathrm{k} \Omega$ ) is lower than that of the inner layer by a factor of eleven $(\mathrm{R} 2=66 \mathrm{k} \Omega$ ), supporting the hypothesis that the corrosion resistance is determined by the dense inner layer.

\subsubsection{Ti-6Al-4V coated specimens}

In the case of C1, C2 and C 3 coatings, R1 is the charge transfer resistance produced by coating layer and R2 is the charge transfer resistance that occurs on surface of the substrate. CPE1 and CPE2 are constant phase elements used to replace the double layer capacitance of the barrier layer. In other words, R1 represents the resistance of the coating layer resulted from the coating defects (pores) and R2 is the charge transfer resistance of the coating/substrate interface. The CPE1 and CPE2 are the capacitances at the solution/coating and coating/ substrate interfaces, respectively. As can be clearly seen in Fig. 7a, data adjusted well to the proposed equivalent circuit (curve in red). The chisquared $\left(\chi^{2}\right)$ average values were of the order of $10^{-3}$ and the error percentages corresponding to each component of the equivalent circuit was $<8 \%$. A perfect concordance, between the experimental curve and the fitted curve was shown in Fig. 7a.

The EIS results (Nyquist and Bode) show that: $\mathrm{C} 1>\mathrm{C} 3>$ Ti-6Al$4 \mathrm{~V}>\mathrm{C} 2$. From Table 5, the inner layer of C2 specimen $(\mathrm{R} 2=24.65$ $\mathrm{k} \Omega$ ) has a slightly higher value than the resistance related to the porous layer $(\mathrm{R} 1=23.2 \mathrm{k} \Omega$ ) and represents the lowest resistance when compared to the other specimens. At the interface coating C2/passive film formed in Hank's solution, the inner layer doesn't play its role as a "barrier layer". The reason was maybe due to the low stability of this passive film. Indeed, Daviðsdóttir et al. [36] reported, in the case of magnetron-sputtered titanium dioxide $\left(\mathrm{TiO}_{2}\right)$, that the transport of charge between the coating and substrate depends on the activation depth of the anatase coating, and any interface oxide layer present on the substrate surface.

\subsection{Tribological behavior}

Quantitative results (wear volume/weight loss) of bone specimens

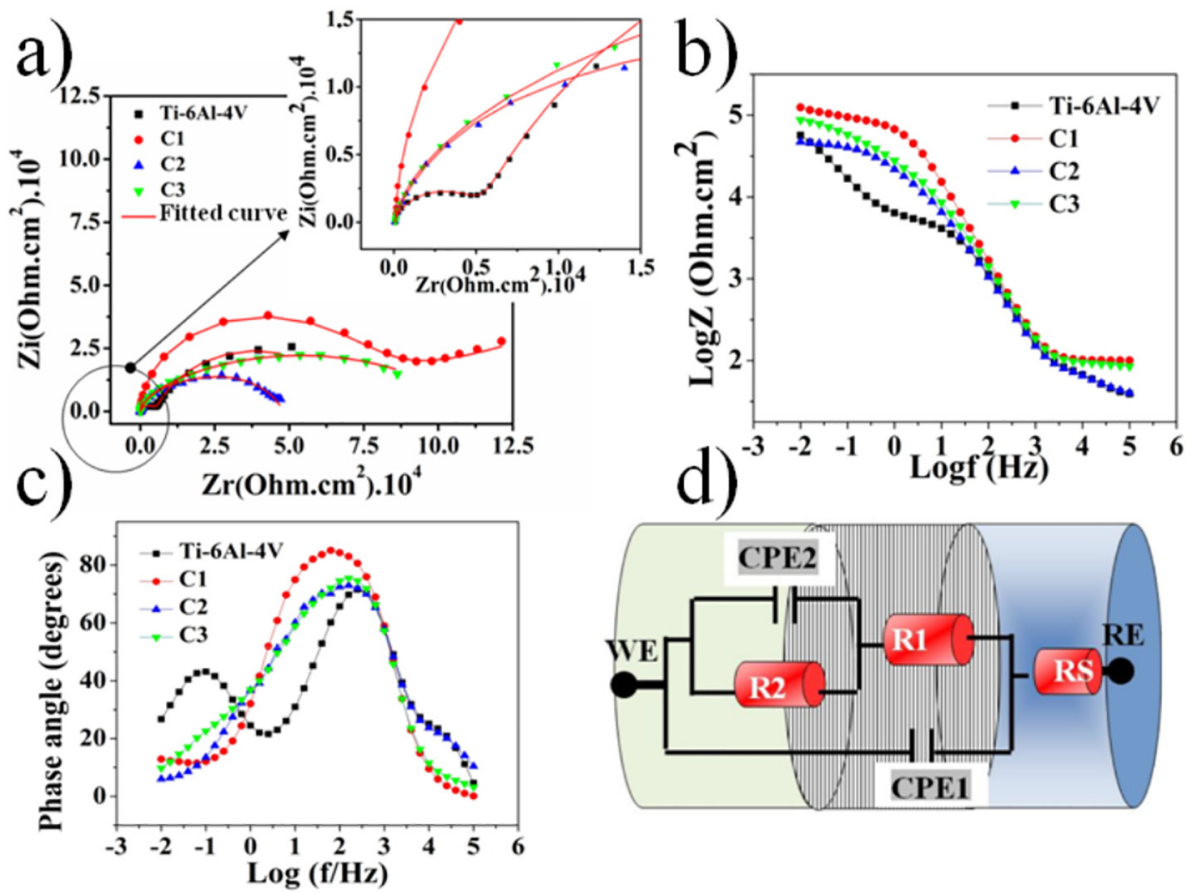

Fig. 7. Electrochemical test results (EIS) in Hank's solution at $37{ }^{\circ} \mathrm{C}$ : (a) Nyquist plots, (b) Bode plots, (c) phase angle Bode plots and (d) equivalent circuit model $(\mathrm{WE}=$ working electrode and $\mathrm{RE}=$ reference electrode). (For interpretation of the references to color in this figure, the reader is referred to the web version of this article.) 
Table 5

Electrochemical impedance parameters of coatings and uncoated Ti-6Al-4V in Hank's solution at $37{ }^{\circ} \mathrm{C}$. Data are the average values of three tests.

\begin{tabular}{|c|c|c|c|c|c|c|c|}
\hline Sample & $\begin{array}{l}\mathrm{R}_{\mathrm{s}} \\
(\Omega)\end{array}$ & $\begin{array}{l}\text { CPE1 } \\
\left(\mu \mathrm{F} / \mathrm{cm}^{2}\right) \cdot \mathrm{E}^{-6}\end{array}$ & $\alpha_{1}$ & $\begin{array}{l}\mathrm{R}_{1} \\
(\mathrm{k} \Omega)\end{array}$ & $\begin{array}{l}\text { CPE2 } \\
\left(\mu F / \mathrm{cm}^{2}\right) \cdot E^{-6}\end{array}$ & $\alpha_{2}$ & $\begin{array}{l}\mathrm{R}_{2} \\
(\mathrm{k} \Omega)\end{array}$ \\
\hline Ti-6Al-4V & 45.82 & 3.5 & 0.85 & 5.5 & 92.9 & 0.79 & 66.32 \\
\hline $\mathrm{C} 1$ & 99.87 & 1.1 & 0.98 & 75.1 & 43.8 & 0.52 & 107.32 \\
\hline $\mathrm{C} 2$ & 45.93 & 4.3 & 0.84 & 23.2 & 22.2 & 0.72 & 24.65 \\
\hline C3 & 88.67 & 1.6 & 0.94 & 10.4 & 13.6 & 0.51 & 94.590 \\
\hline
\end{tabular}

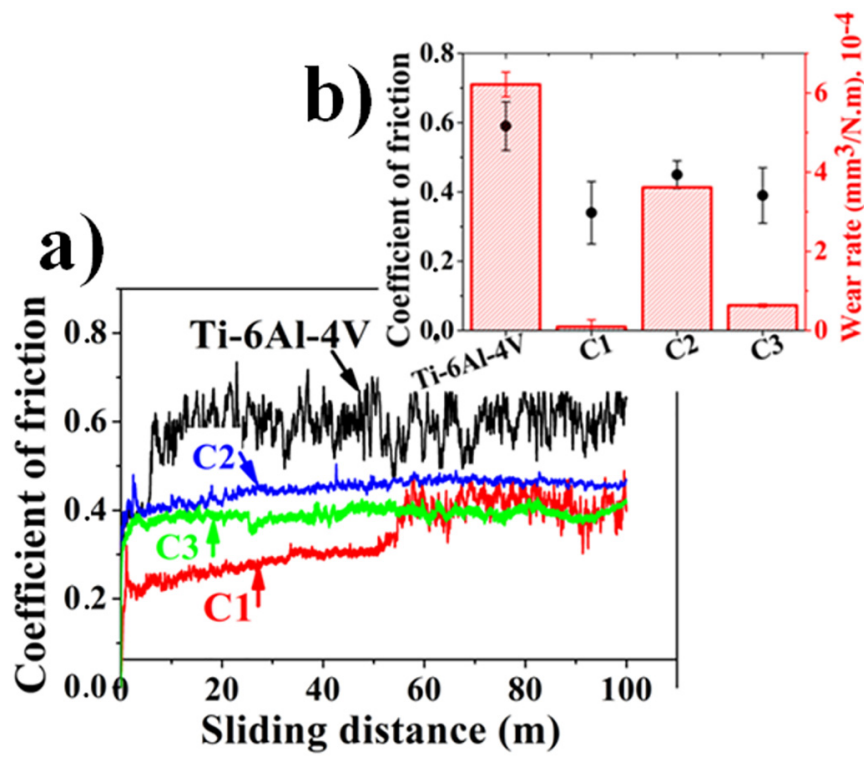

Fig. 8. Tribological test results: (a) COF evolution and (b) estimated specific wear rates and COF values at the steady state. are not so easy to obtain by simple sliding tests. In any cases they are not reproducible. The principal reason was the structural constitution of bone. As defined in literature, bone is built up of mineralized collagen fibrils [37]. The term of "structure" refers to its constitution based on the circular osteons as demonstrated in previous works [24].

\subsubsection{Coefficient of friction (COF)}

Fig. 8 displays tribological results of tested samples against bone pins under Hank's solution lubrication condition at $37^{\circ} \mathrm{C}$. Fig. 8 a shows the $\mathrm{COF}$ as a function of the sliding distance. At the beginning of the test, the initial COF's values are the lowest but then, they increase abruptly to a second stage. The friction coefficient of Ti-6Al-4V substrate was unstable and weaves around 0.6 during the total sliding distance of $100 \mathrm{~m}$. It is a sign of a severe wear. C1 specimen showed the lowest values; $0.2<\mathrm{COF}<0.3$ before $50 \mathrm{~m}$ and becomes $0.3<\mathrm{COF}<0.4$ until the end of the test. Its average value was 0.38 (Fig. 8b). C2 and C3 reached the steady state at the beginning of the test (after a few meters of sliding) when compared to C1.

Fig. $8 \mathrm{~b}$ displays the average value of $\mathrm{COF}$ at the steady-state and specific wear rates estimated based on the volume loss. It reveals that the best performance was shown by $\mathrm{C} 1$ specimen as expected while the worst was for the Ti-6Al-4V substrate. In the first stage, friction was controlled by the difference in hardness and surface roughness. Bone pin was the first damaged antagonist pair because it has the lowest mechanical properties. After more and more sliding cycles, an increase of temperature occurs and the surface asperities of bone are worn. Consequently the wear debris would form an adhesive oxide film on the
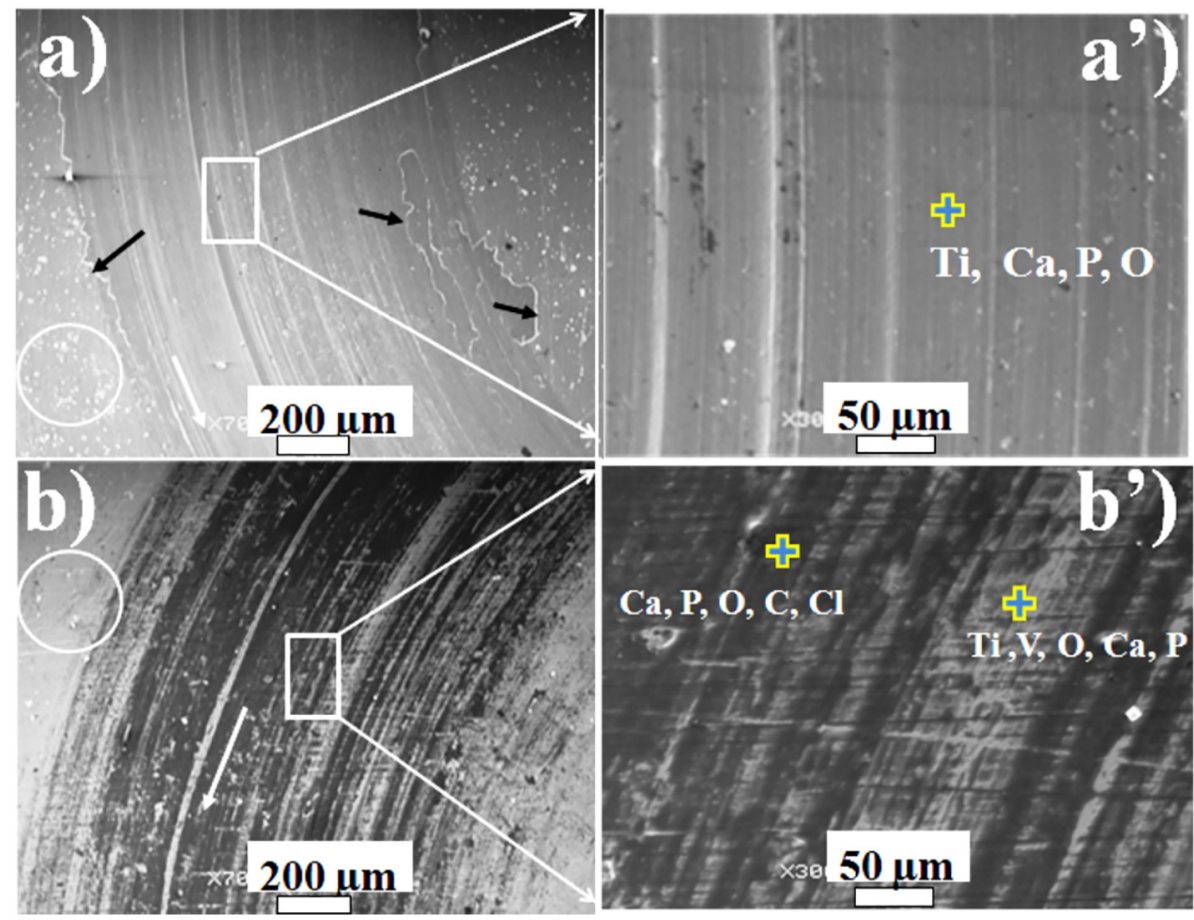

Fig. 9. SEM images of the wear tracks after tribological test in Hank's solution at $37^{\circ} \mathrm{C}$ of: (a) $\mathrm{C} 1$, (b) $\mathrm{C} 2$. Images (a'- $\mathrm{b}^{\prime}$ ) are the magnification of the corresponding areas in (a) and (b). 
interface between the antagonist pair. Hence, the contact area increases leading to a higher friction force. Besides, hard and abrasive debris are generated from the entire tribological pair in contact (debris mixture between bone and disc) leading to the second stage characterized by a severe abrasive wear. This result (Fig. 8b) supports the COF evolution observed in Fig. 8a. Nevertheless, the results of Fig. $8 \mathrm{~b}$ should be taken with care due to the lack of data and because they are substantially lower than others obtained in the literature [23]. Besides, it is clear that Hank's solution doesn't play any role of lubrication in this contact pair.

\subsubsection{Wear mechanisms analysis}

The SEM images (Fig. 9) of wear tracks of two representative specimens i.e. $\mathrm{C} 1$ and $\mathrm{C} 2$ show the wear mechanisms involved during the tribological tests. From Fig. 9a-b, grooves, scratches and furrows are clearly shown, running parallel to the sliding direction (white arrows) indicating that samples have undergo a severe abrasive wear. That is the reason of a relatively high COF observed in Fig. 8. Abrasion zones as well as areas outside the wear track were covered by significant quantities of wear debris (circled areas). Black arrows indicate traces of coating delamination at the edges of the wear track; that means disappearance of the coating after sliding tests.

The coating delamination was usually caused by the residual stresses in the substrate. However after wear tests, the detachment of the coating on either side of the wear track can occur [38]. The film delamination in this case is probably due to: (i) the deterioration (abrasion) of the coating during the sliding test, layer by layer, becoming very thin in the area of the wear track, after more and more cycles. As a consequence, the delamination of the "residual thin coating" occurred at the border of the wear track maybe when the fatigue strength limit of the sublayers located under the wear track was reached i.e. at the interface limit between sub-surface areas undergoing load/unload cycles and free sub-surface areas; (ii) the bonding strength (adhesion between substrate/coating) provided by the used PVD method was not sufficient enough to avoid such delamination in these specific areas.

Further, Fig. $9\left(a^{\prime}-b^{\prime}\right)$ shows on one hand, deeply imbedded debris, pores and voids (traces of removal particles) inside grooves. On another hand, EDS analyses carried out in the wear tracks reveal the presence of bone elements (inside groove (part $a^{\prime}$ ) and in dark zone (part $\left.b^{\prime}\right)$ ), coating elements (inside groove (part $\mathrm{a}^{\prime}$ ) and in gray zone (part $\left.\mathrm{b}^{\prime}\right)$ ) and oxygen. It suggests a transfer from bone pin to coating surface.

Fig. 10 shows SEM images of wear scar of one bone pin taken as an example (counterpart against C1 specimen). From Fig. 10a, one can note a higher damage and deterioration of the pin in comparison to the disc. The magnified area of the worn surface shows large cracks (Fig. 10b), scratches and wear debris (Fig. 10c). EDS analyses of the wear debris (particle inside the area labeled 3 in Fig. 10c) indicates the presence of oxygen, organic elements ( $\mathrm{Na}, \mathrm{Ca}, \mathrm{Cl}, \mathrm{P} \ldots$ ) and $\mathrm{Ti}$ (Fig. 10d). These results are signs of a third body abrasive wear mechanism.

Finally, sliding wear of Ti-6Al-4V coated specimens according to C1 or $\mathrm{C} 2$ design, in Hank's solution at $37{ }^{\circ} \mathrm{C}$ undergo an oxidative wear in the initial stage followed by a third body abrasive wear. The damage process seems to be as follows: at the beginning of the test, debris products come from the bone pin. After that, the pin surface in contact against the coating specimen becomes harder and rougher as a consequence of friction and increase in temperature. Thus, an "adhesive film" could be created between the antagonist surfaces in contact containing hard and abrasive particles (third body). The "adhesive film" consists of a mixture between molecules (Hank's solution), fragments of biological tissues, collagen (bone) and Ti-nitrides, Ti-oxides particles (tested specimen) sticking together. As a result, when specimen rub against bone, abrasion of the tribological pair in contact occurs.

\section{Conclusion}

Multilayered coatings were deposited on Ti-6Al-4V samples by DC reactive magnetron sputtering. Two types of coatings were studied: some films have TiN as upper layer (C1) while $\mathrm{TiO}_{2}$ with 2 different oxygen content was the top layer of the others ( $\mathrm{C} 2$ and $\mathrm{C} 3$ ). Obtained microstructures reveal the crystallinity of TiN single phase for $\mathrm{C} 1$ and anatase titanium dioxide for $\mathrm{C} 2$ and C3 coatings. All the specimens tested in Hank's solution at $37{ }^{\circ} \mathrm{C}$, exhibit similar electrochemical
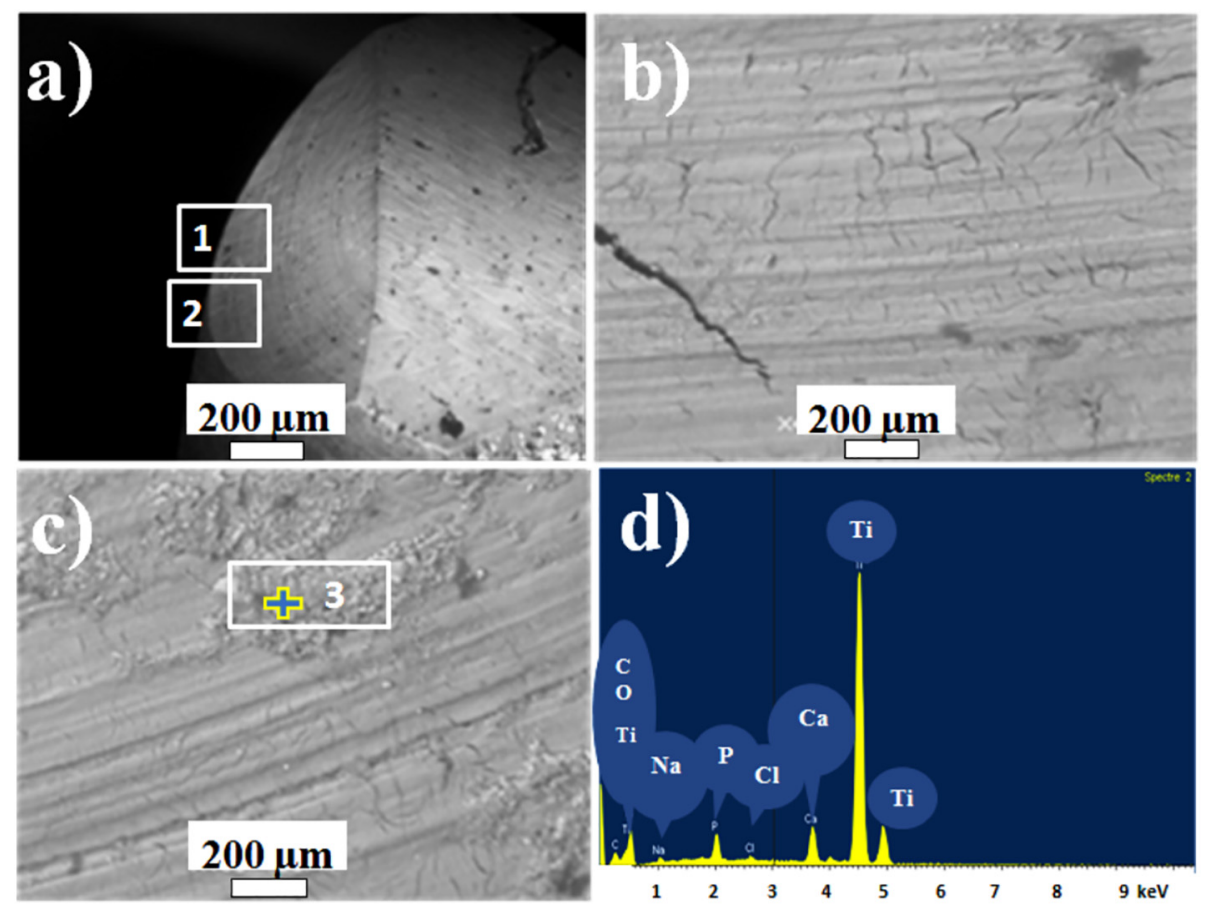

Fig. 10. SEM images of bone pin after tribological test against specimen C1: (a) overview of the wear scar, (b) and (c) magnification of areas labeled 1 and 2, and (d) EDS Spectrum of particles analyzed in area labeled 3. 
corrosion properties. The PVD layers could effectively enhance the corrosion resistance. The TiN upper layer presents the best tribological performances when against bovine cortical bone. The mean mechanism of wear involved during sliding tests was a severe third body abrasion wear. The $\mathrm{TiO}_{2}$ upper layer doesn't play any role in the reduction of friction as well as any inhibition of corrosion, regardless biocompatibility performances, in the conditions adopted in this study.

\section{CRediT authorship contribution statement}

R. Bahi: Formal analysis. C. Nouveau: Formal analysis. N.E. Beliardouh: Supervision, Writing - original draft, Formal analysis. C.E. Ramoul: Formal analysis. S. Meddah: Investigation. O. Ghelloudj: Investigation.

\section{Declaration of competing interest}

The authors declare that they have no known competing financial interests or personal relationships that could have appeared to influence the work reported in this paper.

\section{Acknowledgements}

The authors are grateful to colleagues from LaBoMaP (Arts \& Métiers -Institute of Technology, Cluny, France) and LIS (Annaba, Algeria) laboratories for providing facilities to carry out this work. The authors want also to thank Dr. Aouadi Khalil for his help during the coating depositions.

\section{References}

[1] G. Mendonça, D.B.S. Mendonça, F.J.L. Aragão, L.F. Cooper, Advancing dental implant surface technology - from micron- to nanotopography, Biomaterials 29 (2008) 3822-3835, https://doi.org/10.1016/j.biomaterials.2008.05.012.

[2] C. Yao, T.J. Webster, Anodization: a promising nano-modification technique of titanium implants for orthopedic applications, J. Nanosci. Nanotechnol. 6 (2006) 2682-2692, https://doi.org/10.1166/jnn.2006.447.

[3] W. Cui, G. Qin, J. Duan, H. Wang, A graded nano-TiN coating on biomedical Ti alloy: low friction coefficient, good bonding and biocompatibility, Mater. Sci. Eng. C 71 (2017) 520-528, https://doi.org/10.1016/j.msec.2016.10.033.

[4] M. Kaur, K. Singh, Review on titanium and titanium based alloys as biomaterials for orthopaedic applications, Mater. Sci. Eng. C (2019), https://doi.org/10.1016/j. msec.2019.04.064.

[5] H.A. Ching, D. Choudhury, M.J. Nine, N.A. Abu Osma, Effect of surface coating on reducing friction and wear of orthopedic implants, Sci. Technol. Adv. Mater. 15 (2014) 014402, https://doi.org/10.1088/1468-6996/15/1/014402.

[6] X.J. Wang, Y.C. Li, P.D. Hodgson, C.E. Wen, Nano- and macro-scale characterisation of the mechanical properties of bovine bone, Mater. Forum 31 (2007) 156-159.

[7] S. Tamilselvi, H. Balaji Raghavendran, P. Srinivasan, N. Rajendran, In vitro and in vivo studies of alkali- and heat-treated Ti-6Al-7Nb and Ti-5Al-2Nb-1Ta alloys for orthopedic implants, J. Biomed. Mater. Res. A 90 (2009) 380-386, https://doi.org/ 10.1002/jbm.a.32099.

[8] J. Guo, R.J. Padilla, W. Ambrose, I.J. De Kok, L.F. Cooper, The effect of hydrofluoric acid treatment of $\mathrm{TiO} 2$ grit blasted titanium implants on adherent osteoblast gene expression in vitro and in vivo, Biomaterials 28 (2007) 5418-5425, https://doi.org/ 10.1016/j.biomaterials.2007.08.032.

[9] V. Hernández-Montes, C.P. Betancur-Henao, J.F. Santa-Marín, Titanium dioxide coatings on magnesium alloys for biomaterials: a review, Dyna 84 (2017) 261-270, https://doi.org/10.15446/dyna.v84n200.59664.

[10] K. Shukla, R. Rane, J. Alphonsa, P. Maity, S. Mukherjee, Structural, mechanical and corrosion resistance properties of $\mathrm{Ti} / \mathrm{TiN}$ bilayers deposited by magnetron sputtering on AISI 316L, Surf. Coat. Technol. 324 (2017) 167-174, https://doi.org/10. 1016/j.surfcoat.2017.05.075.

[11] L. Chenglong, Y. Dazhi, L. Guoqiang, Q. Min, Corrosion resistance and hemocompatibility of multilayered Ti/TiN-coated surgical AISI 316L stainless steel, Mater. Lett. 59 (2005) 3813-3819, https://doi.org/10.1016/j.matlet.2005.06.058.

[12] M. Herranen, U. Wiklund, J.-O. Carlsson, S. Hogmark, Corrosion behaviour of Ti/ TiN multilayer coated tool steel, Surf. Coat. Technol. 99 (1998) 191-196, https:// doi.org/10.1016/S0257-8972(97)00525-2.

[13] M. Nordin, M. Herranen, S. Hogmark, Influence of lamellae thickness on the corrosion behaviour of multilayered PVD TiN/CrN coatings, Thin Solid Films 348 (1999) 202-209, https://doi.org/10.1016/S0040-6090(99)00192-3.

[14] B. Tian, D.B. Xie, F.H. Wang, Corrosion behavior of TiN and TiN/Ti composite films on Ti6Al4V alloy in Hank's solution, J. Appl. Electrochem. 39 (2009) 447-453, https://doi.org/10.1007/s10800-008-9690-4.

[15] W. Yanfeng, L. Zhengxian, W. Haonan, D. Jihong, Z. Changwei, Effect of multilayered structure on properties of Ti/TiN coating, Rare Metal Mater. Eng. 46 (2017) 1219-1224, https://doi.org/10.1016/s1875-5372(17)30140-6.

[16] C.L. Jiang, H.L. Zhu, K.S. Shin, Y.B. Tang, Influence of titanium interlayer thickness distribution on mechanical properties of Ti/TiN multilayer coatings, Thin Solid Films 632 (2017) 97-105, https://doi.org/10.1016/j.tsf.2017.04.026. Jiang C.L.

[17] E. Bogdanov, Y. Vavilina, N. Shusharina, A. Goykhman, M. Patrushev, The particles precipitation and osseointegration of a TiO2 thin-film coating by ion beam deposition - an in vivo study, J. Nanomed. Nanotechnol. 5 (189) (2014) 1-6, https:// doi.org/10.4172/2157-7439.1000189.

[18] G. Longo, C.A. Ioannidu, A.S. D'Abusco, F. Superti, C. Misiano, R. Zanoni, et al. Improving osteoblast response in vitro by a nanostructured thin film with titanium carbide and titanium oxides clustered around graphitic carbon, PLoS One 11 (2016) 1-22, https://doi.org/10.1371/journal.pone.0152566.

[19] J. Heinrichs, T. Jarmar, U. Wiklund, H. Engqvist, Physical vapour deposition and bioactivity of crystalline titanium dioxide thin films, Trends Biomater. Artif. Organs 22 (2008) 100-106.

[20] A. Lin, M.A. Meyers, Growth and structure in abalone shell, Mater. Sci. Eng. A 390 (2005) 27-41, https://doi.org/10.1016/j.msea.2004.06.072.

[21] J.B. Park, J.D. Bronzino, Biomaterials: Principles and Applications, CRC press, Boca Raton, London, New York, Washington, D.C, 2003.

[22] C. Wang, G. Zhang, Z. Li, X. Zeng, Y. Xu, S. Zhao, et al., Tribological behavior of Ti$6 \mathrm{Al}-4 \mathrm{~V}$ against cortical bone in different biolubricants, J. Mech. Behav. Biomed. Mater. 90 (2019) 460-471, https://doi.org/10.1016/j.jmbbm.2018.10.031.

[23] C. Ramoul, N.E. Beliardouh, R. Bahi, C. Nouveau, A. Djahoudi, M.J. Walock, Surface performances of PVD ZrN coatings in biological environments, Tribol. Mater. Surf. Interfaces 13 (2019) 12-19, https://doi.org/10.1080/17515831.2018.1553820.

[24] D. Rafieian, W. Ogieglo, T. Savenije, R.G.H. Lammertink, Controlled formation of anatase and rutile TiO2 thin films by reactive magnetron sputtering, AIP Adv. 5 (2015), https://doi.org/10.1063/1.4931925.

[25] A. Wiatrowski, M. Mazur, A. Obstarczyk, D. Wojcieszak, D. Kaczmarek, J. Morgiel, D. Gibson, Comparison of the physicochemical properties of TiO2 thin films obtained by magnetron sputtering with continuous and pulsed gas flow, Coatings 8 (2018) 412, https://doi.org/10.3390/coatings8110412.

[26] H. Wu, X. Zhang, X. He, M. Li, X. Huang, R. Hang, B. Tang, Wear and corrosion resistance of anti-bacterial Ti-Cu-N coatings on titanium implants, Appl. Surf. Sci. 317 (2014) 614-621, https://doi.org/10.1016/j.apsusc.2014.08.163.

[27] M. Chellappa, U. Vijayalakshmi, Improved corrosion resistant and mechanical behavior of distinct composite coatings (silica/titania/zirconia) on Ti-6Al-4V deposited by EPD, J. Asian Ceram. Soc. 5 (2017) 326-333, https://doi.org/10.1016/j. jascer.2017.06.005.

[28] Q. Wang, F. Zhou, C. Wang, M.F. Yuen, M. Wang, T. Qian, M. Matsumoto, J. Yan, Comparison of tribological and electrochemical properties of TiN, $\mathrm{CrN}$, TiAlN and aC:H coatings in simulated body fluid, Mater. Chem. Phys. 158 (2015) 74-81, https://doi.org/10.1016/j.matchemphys.2015.03.039.

[29] N.R.N. Masdek, A.A. Rozali, M.C. Murad, Z. Salleh, Effect of protein concentration on corrosion of Ti-6Al-4V and 316L SS alloys, ISIJ Int. 58 (2018) 1519-1523, https://doi.org/10.2355/isijinternational.isijint-2018-183.

[30] M.J. Runa, M.T. Mathew, L.A. Rocha, Tribocorrosion response of the Ti6Al4V alloys commonly used in femoral stems, Tribol. Int. 68 (2013) 85-93, https://doi.org/10. 1016/j.triboint.2013.09.022.

[31] I.C. Lavos-Valereto, S. Wolynec, I. Ramires, A.C. Guastaldi, I. Costa, Electrochemical impedance spectroscopy characterization of passive film formed on implant Ti-6AI7Nb alloy in Hank's solution, J. Mater. Sci. Mater. Med. 15 (2004) 55-59, https:// doi.org/10.1023/B:JMSM.0000010097.86245.74.

[32] F. Movassagh-Alanagh, A. Abdollah-zadeh, M. Aliofkhazraei, M. Abedi, Improving the wear and corrosion resistance of Ti-6Al-4V alloy by deposition of TiSiN nanocomposite coating with pulsed-DC PACVD, Wear 390 (2017) 93-103, https://doi. org/10.1016/j.wear.2017.07.009.

[33] V.A. Alves, R.Q. Reis, I.C.B. Santos, D.G. Souza, T. de, M.A. Pereira-da-Silva, A. Rossi, L.A. da Silva, In situ impedance spectroscopy study of the electrochemical corrosion of Ti and Ti-6Al-4V in simulated body fluid at $25^{\circ} \mathrm{C}$ and $37{ }^{\circ} \mathrm{C}$, Corros. Sci. 51 (2009) 2473-2482, https://doi.org/10.1016/j.corsci.2009.06.035.

[34] I. Milošev, M. Metikoš-Huković, H.H. Strehblow, Passive film on orthopaedic TiAlV alloy formed in physiological solution investigated by X-ray photoelectron spectroscopy, Biomaterials 21 (2000) 2103-2113, https://doi.org/10.1016/S01429612(00)00145-9.

[35] I.M. Pohrelyuk, V.M. Fedirko, O.V. Tkachuk, R.V. Proskurnyak, Corrosion resistance of Ti-6Al-4V alloy with nitride coatings in Ringer's solution, Corros. Sci. 66 (2013) 392-398, https://doi.org/10.1016/j.corsci.2012.10.005.

[36] S. Daviðsdóttir, R. Shabadi, A.C. Galca, I.H. Andersen, K. Dirscherl, R. Ambat, Investigation of DC magnetron-sputtered TiO2 coatings: effect of coating thickness, structure, and morphology on photocatalytic activity, Appl. Surf. Sci. (2014), https://doi.org/10.1016/j.apsusc.2014.06.047.

[37] S. Weiner, H.D. Wagner, THE MATERIAL BONE: structure-mechanical function relations, Annu. Rev. Mater. Sci. 28 (1998) 271-298, https://doi.org/10.1146/ annurev.matsci.28.1.271.

[38] A. Esguerra-Arce, N.A. Arteaga, C. Amaya, L. Ipaz, N. Alba de Sanchez, Y. Aguilar, An approximation of tribological behavior of Ti1-xAlxN coatings against animal bone in ringer's solution, Rev. Mex. Fis. 60 (2014) 222-226. 